\title{
ANALISIS FAKTOR-FAKTOR YANG MEMPENGARUHI KINERJA USAHA KECIL DAN MENENGAH KABUPATEN MANOKWARI
}

\author{
Yuyun Puji Rahayu', Selmi Dedi ${ }^{2}$, Jein SrianaToyib ${ }^{3}$ \\ Fakultas Ekonomi Dan Bisnis, Universitas Papua, Manokwari
}

\begin{abstract}
Abstrak
Keberadaan Usaha Kecil dan Menengah (UKM) memiliki peran yang strategis dalam mendukung pertumbuhan ekonomi lokal dan penyerapan tenaga kerja. Tujuan penelitian ini adalah untuk menganalisis pengaruh dari sumber daya perusahaan, kapabilitas usaha, dan strategi usaha terhadap kinerja UKM di Kabupaten Manokwari. Penelitian dilakukan dengan pendekatan survei dan dijelaskan secara deskriptif menggunakan tabel dan grafik. Data diperoleh dari hasil wawancara dan pendistribusian kuesioner pada pelaku UKM di Kabupaten Manokwari. Penelitian ini menggunakan teknik accidental dan proportional sampling dengan jumlah sampel sebanyak 100 pelaku UKM. Hasil penelitian menunjukkan bahwa sumber daya perusahaan dan kapabilitas usaha secara signifikan merupakan faktor yang mempengaruhi kinerja UKM, sementara strategi usaha tidak mempengaruhi kinerja UKM di Kabupaten Manokwari.
\end{abstract}

Kata Kunci : UKM, sumber daya perusahaan, kapabilitas usaha, strategi usaha.

\begin{tabular}{l|l} 
Abstract & $\begin{array}{l}\text { The existence of Small and Medium Enterprises (SMEs) has a strategic role to support local } \\
\text { economic growth and create employment. This study aims to analyze the influence of } \\
\text { company resources, business capabilities, and business strategy on the performance of SMEs } \\
\text { in Manokwari Regency. This research is a descriptive study applying survey approach. Data } \\
\text { were obtained from interviews and questionnaires distribution. Using accidental and } \\
\text { proportional sampling, the collected sample was consisted of 100 SMEs in Manokwari } \\
\text { Regency. The results showed that company resources and business capability had a } \\
\text { significant influence on the performance, while business strategy did not affect the } \\
\text { performance of SMEs in Manokwari Regency. }\end{array}$
\end{tabular}

Keywords : $\quad$ SMEs, company resources, business capability, business strategy. 


\section{Pendahuluan}

Dengan luas wilayah dan melimpahnya sumber daya alam yang berada di Kabupaten Manokwari maka peran sektor usaha kecil dan menengah (UKM) sangat diperlukan untuk dapat memanfaatkan kekayaan alam yang melimpah sebagai sumber daya perusahaan. Adapun perkembangan industri kecil dan menengah di Kabupaten Manokwari pada tahun 2013 berdasarkan unit usahanya adalah sektor industri pangan 201 usaha, sektor industri sandang dan kulit 3 usaha, sektor kimia dan bahan bangunan 71 usaha dan sektor kerajinan dan umum ada 4 usaha (BPS Kabupaten Manokwari, 2016). Secara nasional, usaha kecil menengah mampu menjadi penopang perekonomian negara pasca krisis karena memiliki industri yang cukup banyak dan ada dalam setiap sektor ekonomi. Selain itu, usaha kecil menengah penawaran kesempatan kerja cukup banyak, kontribusinya terhadap PDB cukup signifikan dan nilai ekspornya cukup stabil (Hadiyati, 2011).

Pengembangan usaha kecil menengah perlu terus digiatkan terlebih dalam menghadapi kondisi perekonomian sekarang yang berfluktuaktif dan dalam menghadapi Asean Economic Community tahun 2015 ini. Persaingan yang semakin tajam antara pelaku ekonomi usaha kecil menengah, daya saing usaha kecil menengah sebagai industri kreatif dan inofatif, standar desain dan kualitas produk yang ditetapkan oleh ASEAN (ISO26000) merupakan tantangan umum yang dihadapi usaha kecil menengah dalam Masyarakat Economic Asean saat ini. Anggarani, Prasetyoning, \& Safitri (2015) menyatakan bahwa rendahnya produktivitas usaha kecil menengah disebabkan oleh faktor internal yang menurunkan produktivitas seperti kurangnya kemampuan SDM (manajemen SDM, penguasaan teknologi dan pemasaran) dan juga masalah eksternal seperti legalitas formal usaha kecil menengah dan besarnya biaya transaksi yang disebabkan oleh iklim usaha yang kurang mendukung.

Banyak faktor yang mempengaruhi perkembangan usaha kecil menengah. Selain faktor eksternal yang disebabkan oleh perubahan ekonomi makro Indonesia, sisi mikro ekonomi usaha kecil menengah juga menjadi faktor yang turut mempengaruhi. Kendala krusial yang dihadapi oleh usaha kecil menengah meliputi: keterbatasan permodalan, kesulitan dalam bidang pemasaran, keterbatasan keterampilan sumberdaya manusia, kesulitan dalam memperoleh bahan baku, dan teknologi yang masih tradisional. Kendala yang dihadapi dinas terkait dalam upaya pengembangan usaha kecil dan menengah antara lain; sumber daya manusia yang terbatas baik kualitas dan kuantitasnya, keterbatasan dana yang dianggarkan, keterbatasan sarana dan prasarana, serta keterbatasan minat pelaku usaha (Sani, 2017).

Selain permasalahan terkait produksi, ciri khas dari usaha kecil dan menengah yang informal dan sederhana serta pemahaman pelaku usaha tentang pengembangan usahanya juga menjadi penghambat dalam pengembangan usaha (Ulum \& Kurniawan, 2018). Menurut Margaretha \& Khairunisa (2016), faktor penghambat berkembangnya usaha kecil dan menengah adalah kondisi keuangan dan pemodalan. Dimana pelaku usaha, dengan karakteristik yang telah disebutkan sebelumnya, menjadi non-bankable dan juga harus menghadapi ketidakpastian bisnis. Aziz \& Wicaksono (2016) juga menyebutkan bahwa meskipun program pemerintah untuk menunjang pengembangan usaha kecil dan menengah melalui kredit usaha telah diterapkan, default dan overdemand menghasilkan imperfect kredit market. Pada akhirnya UKM lokal terancam shutdown usahanya karena tidak dapat mempertahankan eksistensinya atas perilaku pasar yang semakin terbuka (Sudaryanto, Ragimun, \& Wijayanti, 2013; Syukriah \& Hamdani, 2013).

Kabupaten Manokwari meskipun hanya kota kecil dengan 279 unit industri kecil (BPS, 2016) di Indonesia bagian timur juga terdampak oleh aktivitas MEA. Masuknya kebijakan MEA menimbulkan kekhawatiran pelaku usaha terutama dalam kemampuan UKM-nya untuk berdaya saing. Pesimisme pelaku usaha di Kabupaten Manokwari atas penerapan kebijakan MEA yaitu terganggunya performa usaha kecil menengah dalam mempertahankan produktivitas diatas serangan produk dari luar. Walaupun 
persiapan terhadap usaha kecil menengah telah dilakukan sebelumnya oleh pemerintah dan lembaga pemerhati usaha kecil menengah lainnya, pada kenyataannya usaha kecil menengah di Kabupaten Manokwari terus mengalami kendala yang merupakan faktor internal dalam usahanya. Dengan demikian untuk menjaga kinerja usaha kecil menengah di Kabupaten Manokwari tetap dalam kondisi stabil diperlukan penanganan terhadap permasalahan internal yang dihadapi oleh usaha kecil menengah tersebut.

Berdasarkan kendala yang telah dipaparkan sebelumnya, maka diperlukan adanya konsep pengembangan usaha kecil menengah juga kajian sosial, ekonomi, dan budaya tentang usaha kecil menengah yang ada dalam meningkatkan kinerja usaha kecil menengah sebagai pengerak perekonomian masyarakat di Kabupaten Manokwari. Dengan adanya analisis dan pengembangan kajian tentang sumber daya perusahaan, kapabilitas usaha, strategi usaha, terhadap kinerja usaha kecil dan menengah di Kabupaten Manokwari dapat diciptakan sebuah konsep baru tentang pengembangan dan penanganan usaha kecil dan menengah yang dapat digunakan untuk mendorong sehingga usaha kecil dan menengah tetap eksis dan survive menghadapi persaingan yang ada. Perhatian terhadap pengembangan usaha kecil dan menengah sangat perlu dikarenakan usaha kecil dan menengah adalah sektor usaha yang dapat menampung tenaga kerja sehingga mengurangi penganguran, dapat meningkatkan sumbangan PDRB daerah (Purwaningsih \& Kusuma, 2015), menggerakan perekonomian masyarakat, sehingga dapat meningkatkan kesejahteraan masyarakat di Kabupaten Manokwari.

Dalam persaingan yang kompetitif antara pelaku ekonomi, secara teoritis keunggulan kompetitif suatu perusahaan dapat dibangun dari sumberdaya internal yang dimilikinya. Dengan adanya perubahan yang sangat cepat pada sisi eksternal perusahaan maka analisis terhadap faktor-faktor internal perusahaan semakin penting untuk dilakukan. Penelitian ini menganalisis faktor internal dari UKM yang terbatas pada tiga faktor utama saja yaitu sumber daya perusahaan, kapabilitas usaha dan strategi.
Tujuan khusus dari penelitian ini adalah menganalisis kinerja usaha kecil menengah, menghasilkan kajian sosial, ekonomi, dan budaya tentang usaha kecil menengah dan kajian model penanganan usaha kecil menengah di Kabupaten Manokwari dalam meningkatkan kinerja usaha kecil menengah sebagai penggerak perekonomian masyarakat yang pada akhirnya meningkatkan kesejahteraan masyarakat.

Adapun kerangka pemikiran teoritis dan hipotesis penelitian dilihat pada Gambar 1 .

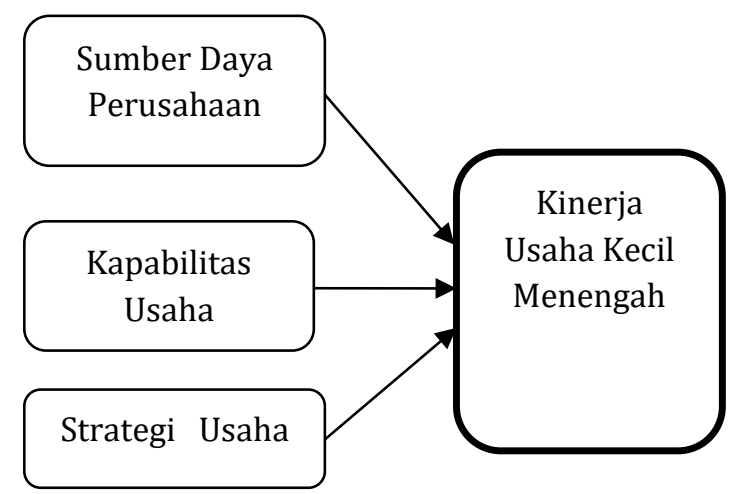

Keterangan:

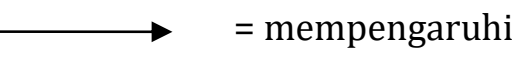

\section{Gambar 1. Kerangka Pikir}

Berpedoman pada kerangka pemikiran teoritis, maka hipotesis penelitian adalah sebagai berikut:

a. Sumber daya perusahaan berpengaruh signifikan terhadap kinerja usaha kecil dan menengah di Kabupaten Manokwari.

b. Kapabilitas usaha berpengaruh signifikan terhadap kinerja usaha kecil dan menengah di Kabupaten Manokwari.

c. Strategi usaha berpengaruh signifikan terhadap kinerja usaha kecil dan menengah di Kabupaten Manokwari.

d. Sumber daya perusahaan, kapabilitas usaha, dan strategi usaha secara simultan berpengaruh signifikan terhadap kinerja usaha kecil dan menengah di Kabupaten Manokwari.

\section{Metodologi}

Jenis dan sumber data dalam penelitian ini adalah data primer yang diperoleh langsung 
dari responden melalui kuisoner dan wawancara langsung dengan pemilik usaha kecil menengah serta dengan pemerintah terkait di Kabupaten Manokwari. Data Sekunder diperoleh dengan mengadakan penelitian dokumenter berupa data dari arsiparsip, buku literatur, diktat dan referensi lain yang relevan dengan masalah penelitian ini seperti data jumlah usaha kecil dan menengah di Kabupaten Manokwari.

Penelitian ini dilakukan di Kabupaten Manokwari dengan objek penelitian sebagai populasi adalah usaha kecil dan menengah yang ada di Kabuaten Manowari. Pengambilan sampel mengunakan teknik accidental sampling, yaitu pengambilan sampel secara kebetulan pada saat dilokasi penelitian yaitu UKM yang bersedia dijadikan responden.

Tabel 1. Populasi dan Sampel Penelitian

\begin{tabular}{clrrr}
\hline No. & \multicolumn{2}{c}{ Populasi } & \multicolumn{3}{c}{ Penarikan Sampel } \\
\cline { 2 - 5 } & $\begin{array}{l}\text { Sektor } \\
\text { Industri }\end{array}$ & $\begin{array}{c}\text { Jumlah } \\
\text { Industri }\end{array}$ & $\begin{array}{c}\text { Persentase } \\
\text { (\%) }\end{array}$ & Sampel \\
\hline 1 & Pangan & 201 & 72 & 72 \\
\hline 2 & $\begin{array}{l}\text { Sandang } \\
\text { \& Kulit }\end{array}$ & 3 & 1 & 3 \\
\hline 3 & $\begin{array}{l}\text { Kimia \& } \\
\text { Bahan } \\
\text { Bangunan }\end{array}$ & 71 & 25 & 25 \\
\hline 4 & $\begin{array}{l}\text { Kerajinan } \\
\text { \& Umum }\end{array}$ & 4 & & \\
\hline & Jumlah & 279 & 2 & 4 \\
\hline
\end{tabular}

Sumber: BPS Kabupaten Manokwari (2016)

Jumlah sampel ditetapkan 100 sampel. Lokasi pengambilan sampel dengan cara proporsional sampling yaitu pengambilan sampel dengan memberikan proporsi menurut jumlah populasi di masing-masing sektor industri. Adapun penarikan sampel dapat dilihat pada tabel 1.

Analisis data kuantitatif digunakan untuk memperkirakan secara kuantitatif pengaruh dari beberapa variabel independen secara bersama-sama maupun secara sendiri-sendiri terhadap variabel dependen. Perumusan model fungsi kinerja usaha kecil dan menengah yang digunakan dalam penelitian ini sebagai berikut:

$\mathrm{Y}=\alpha+\beta_{1} \mathrm{X}_{1}+\beta_{2} \mathrm{X}_{2}+\beta_{3} \mathrm{X}_{3}+e$

dimana :
$\mathrm{Y}=$ Kinerja Usaha Kecil Menengah

$\alpha=$ konstanta

$\beta_{1}, \beta_{2}, \beta_{3}=$ koefisien regresi

$\mathrm{X}_{1}=$ Sumber daya Usaha $\left(\mathrm{X}_{1}\right)$

$\mathrm{X}_{2}=$ Kapabilitas usaha $\left(\mathrm{X}_{2}\right)$

$\mathrm{X}_{3}=$ Strategi usaha $\left(\mathrm{X}_{3}\right)$

$\mathrm{e}=$ error

Ketepatan fungsi regresi sampel dalam menaksir nilai aktual dapat diukur dari Goodness of Fit-nya, uji penyimpangan asumsi klasik, uji F, uji t, maupun uji diagnotis.

Defnisi operasional dalam penelitian ini adalah sebagai berikut.

1. Sumber Daya Perusahaan $\left(\mathrm{X}_{1}\right)$ adalah semua sumber daya usaha kecil dan menengah yang digunakan untuk dalam proses produksi. Dalam penelitian ini sumber daya perusahaan diukur dengan indikator (1) sumber daya financial (2) sumber daya fisik (3) sumber daya manusia.

2. Kapabilitas Usaha $\left(\mathrm{X}_{2}\right)$ dalam penelitian ini adalah kapasitas dari kemampuan usaha kecil dan menengah secara integrasi dalam melakukan ativitas usahanya. Indikator pengukurannya diukur dengan kemampuan yang berharga, kemampuan yang tak dapat ditiru (3) kemampuan yang tak dapat digantikan.

3. Strategi Usaha $\left(\mathrm{X}_{3}\right)$ adalah cara yang ditempuh oleh usaha kecil dan menengah untuk dapat memenangkan persaingan dengan pesainnya.. Pengukurannya dengan indikator (1) diferensiasi (2) kepemimpian biaya menyeluruh,(3) fokus .

4. Kinerja Perusahaan ( $\mathrm{Y}$ ) adalah hasil yang ditampilkan oleh usaha kecil dan menengah dalam menjalankan usahanya. Dalam penelitian ini kinerja perusahaan diukur dengan mengunakan indikator (1) kualitas produk (2) kinerja operasionalnya (3) kinerja keuangan.

\section{Hasil dan Pembahasan}

\section{$\underline{\text { Karakteristik Usaha }}$}

Pelaku usaha yang menjadi responden penelitian ini lebih didominasi oleh responden 
pria dibandingkan reponden wanita, dimana jumlah responden pria lebih dari 50 persen. Pria yang telah berkeluarga memiliki tanggung jawab untuk memberi nafkah kepada keluarga begitu pula pria yang mengambil tanggung tawab menjadi tulang punggung keluarga, sehingga responden menekuni usaha kecil dan menengah. Selanjutnya, tingkat pendidikan seseorang menunjukkan kemampuan dasar seseorang dan dapat menjadi modal dasar pengetahuan pelaku UKM. Responden terbanyak memiliki pendidikan setingkat SMA.

Tabel 2. Karakteristik Usaha Kecil dan Menengah Di Kabupaten Manokwari

\begin{tabular}{ccc}
\hline Indikator & Kategori & $\begin{array}{c}\text { Jumlah Usaha } \\
\text { (Unit) }\end{array}$ \\
\hline Tingkat & Sekolah & 7 \\
Pendidikan & Dasar & \\
Pemilik UKM & SMP & 13 \\
& SMA & 53 \\
Total & Sarjana & 27 \\
Umur Usaha & $<5$ & $\mathbf{1 0 0}$ \\
(Tahun) & $6-10$ & 46 \\
& $11-15$ & 33 \\
& $16-20$ & 14 \\
Total & $>20$ & 2 \\
Kerja & $1-5$ & $\mathbf{1 0 0}$ \\
\hline Jumlah Tenaga & 85 \\
& $6-10$ & 12 \\
Total & $11-15$ & 3 \\
& $>15$ & 0 \\
Modal Usaha & Pribadi & 67 \\
Total & Pinjaman & 33 \\
\hline
\end{tabular}

Sumber: Data primer diolah, 2016

Berdasarkan tabel 2, diketahui bahwa UKM di Kabupaten Manokwari sebagian besar (hampir 50\%) memiliki lama usaha kurang dari lima tahun. Dengan demikian, responden dikelompokkan sebagai pemula dalam menjalankan UKM-nya. Sementara sisanya memiliki lama usaha bervariasi dengan umur usaha terlama hingga 20 tahun. Artinya, sebagian UKM mampu menjalankan strategi, menggunakan sumber daya dan memiliki kapabilitas usaha yang cukup baik.

Memiliki jumlah tenaga kerja 1-5 orang merupakan karakteristik pelaku usaha kecil dan menengah di Kabupaten Manokwari.
Jumlah tenaga kerja yang terbatas ini sesuai dengan karakteristik UKM menurut Sani (2017) yang menyebutkan keterbatasan dalam hal kualitas dan kuantitas sumber daya, termasuk sumber daya manusia pada UKM.

Nilai asset UKM yang dimiliki responden paling banyak berada pada kisaran kurang dari 250 juta. Sedangkan UKM lainnya memiliki nilai asset dibawah 500 juta rupiah dan hanya tiga unit UKM yang memiliki asset diatas 1 milyar rupiah. Sebagian besar pelaku UKM memiliki modal usaha pribadi dan hanya 33 unit UKM yang memilih untuk menambah modal usaha dari lembaga keuangan bank dan non-bank. Sumber modal tidak serta merta menunjukkan skala usaha, namun dalam hal UKM yang pemiliknya lebih memilih menggunakan dana pribadi dapat menunjukkan bahwa skala usaha dan jenis usahanya tergolong sederhana ataupun tradisional (Ulum \& Kurniawan, 2018).

\section{$\underline{\text { Uji Statistik }}$}

Dari perhitungan koefisien determinasi penelitian ini diperoleh nilai R Square sebesar 0,216 atau 21,6 persen kinerja UKM di Kabupaten Manokwari dipengaruhi oleh dipengaruhi oleh Sumber Daya Perusahaan, Kapabilitas Usaha, dan Startegi Usaha. Sisanya sebesar 79,4 persen dipengaruhi oleh variabel lainnya yang belum diteliti pada penelitian ini.

Tabel 3. Hasil Uji Statistik t

\begin{tabular}{|c|c|c|c|c|c|}
\hline \multirow[b]{2}{*}{ Model } & \multicolumn{2}{|c|}{$\begin{array}{c}\text { Unstandardized } \\
\text { Coefficients } \\
\text { Std. }\end{array}$} & \multirow[t]{2}{*}{$\begin{array}{c}\begin{array}{c}\text { Standard } \\
\text { ized } \\
\text { Coefficie } \\
\text { nts }\end{array} \\
\text { Beta } \\
\end{array}$} & \multirow[t]{2}{*}{ t } & \multirow[t]{2}{*}{ Sig. } \\
\hline & B & Error & & & \\
\hline 1 (Cons) & 1,264 & 0,538 & & 2,349 & 0,021 \\
\hline $\mathrm{X} 1$ & 0,348 & 0,113 & 0,292 & 3,085 & 0,003 \\
\hline X2 & 0,292 & 0,103 & 0,269 & 2,823 & 0,006 \\
\hline $\mathrm{X} 3$ & 0,092 & 0,061 & 0,141 & 1,509 & 0,135 \\
\hline
\end{tabular}

Sumber : Data diolah, 2016

Diperoleh nilai Fhitung sebesar 8,734 hasil ini menunjukan bahwa nilai Fhitung $>$ Nilai Ftabel dan nilai signifikansi 0,000 0,005. Maka disimpulkan variabel independen Sumber Daya Perusahaan, Kapabilitas Usaha, dan Startegi Usaha secara Simultan 
berpengaruh terhadap Kinerja UKM di Papua Barat.

Tabel 4. Hasil Uji Koefisien Determinasi

\begin{tabular}{ccccr}
\hline Model & $\mathbf{R}$ & $\begin{array}{c}\text { R- } \\
\text { Square }\end{array}$ & $\begin{array}{c}\text { Adjusted } \\
\text { R Square }\end{array}$ & $\begin{array}{c}\text { Std. Error of } \\
\text { the Estimate }\end{array}$ \\
\hline 1 & 0,465 & 0,216 & 0,191 & 0,4503 \\
\hline Sumber : Data diolah, 2016
\end{tabular}

Berdasarkan hasil uji statistik $\mathrm{t}$ disimpulkan bahwa variabel Sumber Daya Perusahaan dan Kapabilitas Usaha memiliki nilai signifikansi $0,000<0,05$ sedangkan variabel Strategi Usaha memiliki nilai signifikansi $>0,05$ yang artinya Variabel Sumber Daya Perusahaan dan Kapabilitas Usaha berpengaruh secarah signifikan terhadap Kinerja Usaha Kecil Menengah di Kabupaten Manokwari namun Variabel Strategi Usaha tidak berpengaruh terhadap Kinerja Usaha Kecil Menengah. Variabel yang paling berpengaruh terhadap Variabel Kinerja UKM adalah Sumber Daya Perusahaan dengan nilai t hitung 3,085 dan tingkat signifikansi $0.000<0.05$. Dari hasil uji statistik $t$ diperoleh persamaan sebagai berikut:

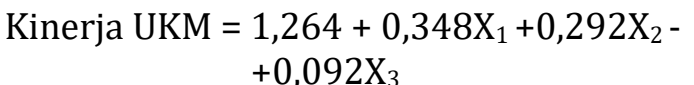

Pada persamaan model terlihat bahwa nilai intersep yang diperoleh sebesar 1,264. Hasil ini menjelaskan bahwa ketika nilai Sumber Daya Perusahaan, Kapabilitas Usaha, dan Startegi Usaha dianggap konstan atau tetap maka terjadi perubahan variabel Kinerja UKM sebesar 1,264.

Koefisien regresi Sumber Daya Perusahaan sebesar 0.348 menyatakan bahwa setiap kenaikan 1 jumlah Sumber Daya Perusahaan akan menaikkan variabel Kinerja Usaha Kecil menengah sebesar 0,348. Koefisien regresi Kapabilitas Usaha sebesar 0.292 menyatakan bahwa setiap kenaikan 1 jumlah Kapabilitas Usaha akan menaikkan variabel Kinerja Usaha Kecil menengah sebesar 0,292. Koefisien regresi Strategi Usaha sebesar 0.092 menyatakan bahwa setiap kenaikan 1 jumlah Strategi Usaha akan menaikkan variabel Kinerja Usaha Kecil menengah sebesar 0,092.

\section{Pembahasan}

Besarnya pengaruh Sumber Daya Perusahaan, Kapabilitas Usaha, dan Startegi Usaha terhadap Kinerja Usaha Kecil Menengah sebesar 0,216 atau 21,6\%. Selain itu, ada sebesar 79,4 \% Kinerja UKM dipengaruhi oleh faktor-faktor lain seperti profitabilitas perusahaan, strategi leadership, Knowledge Management, orientasi wirausaha dan faktorfaktor eksternal perusahaan.

Dari hasil pengujian secara simultan melalui uji statistik $F$ nilai signifikansi 0,000 menunjukkan bahwa variabel independen Sumber Daya Perusahaan, Kapabilitas Usaha, dan Startegi Usaha. secara Simultan berpengaruh terhadap Kinerja UKM di Papua Barat.

Untuk variabel Sumber Daya Perusahaan memiliki nilai t-hitung sebesar 2,349 dengan signifikansinya sebesar 0,03, yang menunjukan bahwa Sumber Daya Perusahaan memberikan pengaruh yang positif dan signifikan terhadap Kinerja Usaha Kecil Menengah di Kabupaten Manokwari. Penelitian ini sejalan dengan penelitian Fauzi, Suharjo, and Syamsun (2016); dan Purwaningsih and Kusuma, (2015) dan (Ardiana, Brahmayanti, \& Subaedi, 2010) yang menjelaskan bahwa Sumber Daya Perusahaan memberikan pengaruh yang positif dan signifikan terhadap Kinerja Usaha Kecil Menengah.

Sebagai faktor penting dari proses produksi tentunya Sumber Daya Perusahaan memberikan pengaruh yang sangat besar bagi keberhasilan sebuah perusahaan dalam memperoleh profit, berkelanjutan dan berkompetisi dengan perusahaan lain. Peranan sumber daya bagi penciptaan keunggulan kompetitif adalah peranan dari semua sumber daya yang ada dalam perusahaan baik sumber daya keuangan, fisik, manusia maupun sumber daya lainnya.

Dalam penelitian ini indikator yang digunakan adalah sumber daya financial, sumber daya fisik dan sumber daya manusia. Hasil penelitian menunjukan bahwa sebagian besar UKM dalam penelitian ini memiliki 
kemampuan finansial untuk memenuhi kebutuhan dana operasional perusahaan. Selain itu dalam akses untuk mendapatkan dukungan dana dari bank maupun lembaga keuangan lain masih tergolong sangat mudah. Hal ini berarti usaha kecil menengah yang ada di Kabupaten Manokwari memiliki kemampuan secara financial untuk mendukung operasional UKM dalam menghasilkan kinerja yang semakin baik. Hasil penelitian ini sejalan dengan Munizu (2010), yang menyatakan bahwa aspek keuangan mempengaruhi kinerja suatu usaha.

Selain itu, ketersediaan bahan baku yang cukup bagi pengembangan UKM serta akses untuk memperoleh bahan baku sebagai faktor input dalam produksi juga menjadi penting bagi keberhasilan UKM. Faktor kunci lainnya dalam sumber daya perusahaan yang sangat berperan penting dalam performance UKM adalah sumber daya manusianya. Kreatifitas dan komitmen yang tinggi dari pelaku UKM untuk dapat mengembangkan diri sesuai kebutuhan dan tuntutan lingkungan bisnis saat ini yang sangat kompetitif tentunya sangat diperlukan. Hal ini sesuai dengan hasil penelitian yang dilakukan oleh Fauzi and Suharjo (2016) yang menyimpulkan bahwa pengembangan SDM diperlukan untuk peningkatan kinerja UKM.

Dukungan dan perhatian pemerintah untuk mendukung perkembangan usaha kecil menengah di Kabupaten Manokwari melalui ketersediaan bahan baku yang murah, akses modal yang mudah, peningkatan kapasitas pelaku UKM harus terus dilakukan untuk mempersiapkan dan mendorong UKM agar terus mampu bersaing dan bertahan ditengah persaingan bisnis yang sangat ketat saat ini. Sani (2017) menyimpulkan bahwa diperlukan kerjasama yang baik antar lembaga terkait di tingkat daerah untuk pengembangan UKM, karena baik dari lembaga maupun pelaku UKM yang menentukan strategi pengembanhan UKM mengalami keterbatasan baik kualitas dan kuantitas SDM, modal dan minat berusaha.

Berdasarkan uji t-hitung, variabel Kapabilitas Usaha menunjukkan nilai sebesar $-2,823$ dengan tingkat signifikansi $0,006 \%$, hal ini berarti bahwa Kapabilitas Usaha memberikan pengaruh positif dan signifikan terhadap Kinerja Usaha Kecil Menengah di Kabupaten Manokwari. Kemampuan pelaku UKM untuk mengintegrasikan sumberdaya yang dimiliki dengan kreatifitas, inovasi dan daya saing yang terwujud dari aktivitas UKM berpengaruh besar terhadap hasil yang dicapai oleh UKM. Kapabilitas usaha kecil dan menengah yang ada di Kabupaten Manokwari berdasarkan hasil penelitian ini masih cukup rendah, hal ini dikarenakan inovasi dalam menghasilkan produk yang masih belum maksimal. Kemampuan untuk mengelola usaha sehingga bisa berkelanjutan dan berkembang belum menjadi prioritas bagi UKM yang ada. Hasil yang diperoleh masih difokuskan kepada pemenuhan usaha saat ini dan belum kepada kontinuitas usaha.

Nilai t-hitung variabel Strategi Usaha sebesar 1,509 dengan nilai signifikansi sebesar 0,135> 0,005, menjelaskan bahwa variabel Strategi Usaha tidak memberikan pengaruh yang signifikan terhadap Kinerja Usaha Kecil Menengah di Kabupaten Manokwari. Lingkup usaha yang masih terbatas serta daya saing yang masih cukup rendah menjadikan strategi dalam mengembangkan usaha belum menjadi hal penting yang dilakukan UKM di Kabupaten Manokwari. Sebagian besar produk yang dihasilkan UKM masih meniru produk yang sudah ada dan belum mampu menciptakan suatu produk baru yang berbeda dan inovatif dari produk yang lain. Diferensiansi produk yang masih terbatas serta fokus usaha yang masih terkosentrasi pada pangsa pasar yang terbatas merupakan kendala UKM untuk meningkatkan hasil kinerja yang lebih maksimal.

\section{Kesimpulan}

Beberapa kesimpulan yang diperoleh dari hasil penelitian adalah Sumber Daya Perusahaan, Kapabilitas Usaha, dan Startegi Usaha secara simultan berpengaruh terhadap Kinerja UKM di Kabupaten Manokwari Papua Barat. Berdasarkan hasil uji statistik t secara parsial disimpulkan bahwa variabel Sumber Daya Perusahaan dan Kapabilitas Usaha berpengaruh secarah signifikan terhadap Kinerja Usaha Kecil Menengah di Kabupaten Manokwari namun Variabel Strategi Usaha 
tidak berpengaruh terhadap Kinerja Usaha Kecil Menengah.

Selanjutnya, lingkup usaha yang masih terbatas serta daya saing yang masih cukup rendah menjadikan strategi Usaha untuk mengembangkan usaha belum menjadi hal penting yang dilakukan UKM di Kabupaten Manokwari. Diferensiansi produk yang masih terbatas serta fokus usaha yang masih terkosentrasi pada pangsa pasar yang terbatas merupakan kendala UKM untuk meningkatkan hasil kinerja yang lebih maksimal.

\section{Saran}

Penelitian ini menganalisis faktor internal dari usaha kecil dan menengah yang terbatas pada tiga faktor utama saja yaitu sumber daya perusahaan, kapabilitas usaha dan strategi. Penelitian selanjutnya dapat dilakukan dengan melihat faktor eksternal yang dapat mempengaruhi kinerja usaha atau melihat strategi pengembangan usaha dengan mempertimbangkan ketiga faktor tersebut, terutama faktor yang menjadi kendala bagi peningkatan kinerja usaha kecil dan menengah.

\section{Daftar Referensi}

Anggarani, A., Prasetyoning, W., \& Safitri, V. I. (2015). Penguatan Sektor Umkm Sebagai Strategi Menghadapi MEA 2015. Jurnal Ekonomi, 5(1), 42-48.

Ardiana, I. D. K. R., Brahmayanti, I. A., \& Subaedi, S. (2010). Kompetensi SDM UKM dan Pengaruhnya Terhadap Kinerja UKM di Surabaya. Jurnal Manajemen Dan Kewirausahaan, 12(1), pp.42-55. https://doi.org/10.9744/jmk.12.1.pp. 42-55

Aziz, A., \& Wicaksono, E. (2016). Analisis Skema Alternatif Kredit Program Untuk Usaha Mikro, Kecil, Dan Menengah. Jurnal Ekonomi Dan Kebijakan Publik, 7(2), 143-157.

BPS Kabupaten Manokwari. (2016). Kabupaten Manokwari Dalam Angka.

Fauzi, A., \& Suharjo, B. (2016). Pengaruh Sumber Daya Finansial , Aset Tidak Berwujud dan Keunggulan Bersaing yang Berimplikasi Terhadap Kinerja Usaha Mikro, Kecil dan Menengah di Lombok NTB. Manajeemn IKM, 11(2), 151-158.
Fauzi, A., Suharjo, B., \& Syamsun, M. (2016). Pengaruh Sumber Daya Finansial , Aset Tidak Berwujud dan Keunggulan Bersaing yang Berimplikasi Terhadap Kinerja Usaha Mikro , Kecil dan Menengah di Lombok NTB. Manajemen IKM, 11(2), 151-158.

Hadiyati, E. (2011). Kreativitas dan Inovasi Berpengaruh Terhadap Kewirausahaan Usaha Kecil. Jurnal Manajemen Dan Kewirausahaan, 13(1). https://doi.org/10.9744/jmk.13.1.8-16

Margaretha, F., \& Khairunisa. (2016). Pengaruh Struktur Modal Dan Likuiditas Terhadap Profitabilitas Pada Usaha Kecil Dan Menengah Di Indonesia. Manajemen Bisnis Kompetensi, 11(2).

Munizu, M. (2010). Pengaruh Faktor-Faktor Eksternal dan Internal Terhadap Kinerja Usaha Mikro dan Kecil (UMK) di Sulawesi Selatan. Jurnal Manajemen Dan Kewirausahaan, 12(1), pp.33-41. https://doi.org/10.9744/jmk.12.1.pp. 33-41

Purwaningsih, R., \& Kusuma, P. D. (2015). Analisis Faktor-faktor yang mempengaruhi Kinerja Usaha Kecil dan Menengah (UKM) dengan metode Structural Equation Modeling (Studi Kasus UKM Berbasis Industri Kreatif Kota Semarang). In Prosiding SNST Fakultas Teknik (pp. 27-31).

Sani, A. (2017). Strategi Dinas Perindustrian, Perdagangan Dan Koperasi Perindagkop) Kabupaten Nagan Raya Dalam Mengembangkan Usaha Kecil Dan Menengah. Jurnal Public Policy, 3(1), 65-76.

Sudaryanto, Ragimun, \& Wijayanti, R. R. (2013). Strategi Pemberdayaan UMKM Menghadapi Pasar Bebas Asean. Pusat Kebijakan Ekonomi Makro. Badan Kebijakan Fiskal. Jakarta.

Syukriah, A., \& Hamdani, I. (2013). Peningkatan Eksistensi Umkm Melalui Comparative Advantage Dalam Rangka Menghadapi MEA 2015 Di Temanggung. Economics Development Analysis Journal, 2(2), 110-119.

Ulum, I., \& Kurniawan, Y. (2018). Model Manajemenkelompok Usaha Mikro Kecil dan Menengah ( UMKM ) Usaha Tepung Tapioka. Aristo, 6(1), 18-44. 